of greater or less strength, and travelling up the stream with different speeds, take the place of the more gentle undulations. The distinction between ring vortices and ring-shaped undulations is perhaps here too strongly and improperly overdrawn, as, besides the improbability that effects so exaggerated as perfect airwhirls are really ever attained in ordinary gas-jets, the properties of the undulations that correspond to and lead up to them in ordinary currents must evidently resemble theirs in all respects, so that the deeper and stronger interior undulations move up the jet more rapidly than open and weaker exterior ones on the surface; for it seems probable that both vortices and ring-waves of strongest rarefaction will generally occur nearest to the centre or axis, and those of weakest rarefaction furthest from it, or nearer to the slow-moving outer surface of the jet. The effect of the collision and destruction of a weaker by a stronger ring-wave, when they overtake each other, is the same as that of perfect circulating whirls; the balance of pressure in one part of the circular wave being broken by a shock, it collapses in every other part, and if both waves are destroyed, the further progress of the jet is intercepted at that point, and it scatters itself in a confused cloud at the point of concourse and disruption of the waves. The long-enduring smoke- or steam-rings often seen projected from the funnels of locomotive engines at starting, or when moving slowly and emitting separate puffs, illustrate apparently the mutual action of closely packed parallel jets like those of an ordinary gauze flame; for the impeded passage to the outer air offered by a number of such surrounding jets, just as by the funnel of the locomotive engine, favours the production of a strong vacuum round the jet-aperture or blast-pipe, and of a strong wave or steam-ring, the moment that the jet or blast takes a side-swing or a sudden leap upwards that calls the action of the partial vacuum into play.

$$
\text { (To be contintued.) }
$$

A. S. Herschei

\section{A New and Simple Method for making Carbon Cells and Plates for Galvanic Batteries}

Some time since a correspondent asked for an easy method to construct carbon plates. A paper of mine was read in Section A at Belfast on the subject, and as it describes a process by which any experimentalist can construct not only plates but cells of carbon, I have thought a condensed account of the process may be appropriate for your columns.

With a syrup made of equal quantities of lump-sugar and water, mix wood-charcoal in powder with about a sixth part of a light powder sold by colourmen, called vegetable black. The mixture should hang thickly on any mould dipped into it, and yet be sufficiently fluid to form itself into a smooth surface. The vegetable black considerably helps in this respect.

Moulds of the cells required are made of stiff paper, and secured by wax or shellac. A projection should be made on the top of the mould for a connecting piece. These moulds are dipped into the carbon syrup, so as to cover the outside only, and then allowed to dry. This dipping and drying is repeated until the cells are sufficiently thick. When well dried they are thea buried in sand, and baked in an oven sufficiently hot to destroy the paper mould. When cleared from the sand and burnt praper the cells are soaked for some hours in dilute hydrochloric acid, and again well dried, then soaked in sugar syrup. When dry they are then packed with sand in an iron box, gradually xaised to a white heat and left to cool. Should some of the cells be cracked, they need not be rejected, but covered with paper or plaster and dipped in melted paraffin.

Rods or plates of carbon can be rolled or pressed out of a similar composition, but made thicker. Carbon thus made will be found to have a good metallic ring and a brilliant fracture.

Barnstaple, Oct. 26

W. SYMONS.

\section{Ingenuity in a Spider}

A SPIDER constructed its web in an angle of my garden, the sides of which were attached by long threads to shrubs at the height of nearly three feet from the gravel path beneath. Being much exposed to the wind, the equinoctial gales of this autumn destroyed the web several times.

The ingenious spider now adopted the contrivance here represented. It secured a conical fragment of gravel with its larger end upwards, by two cords, one attached to each of its opposite sides, to the apex of its wedge-shaped web, and left it suspended as a moveable weight to be opposed to the effect of such gusts of air as had destroyed the webs previously occupying the same situation.

The spider must have descended to the gravel path for this special object, and, having attached threads to a stone suited to its purpose, must have afterwards raised this by fixing itself upon the web, and pulling the weight up to a height of more than two feet from the ground, where it hung suspended by elastic cords. The excellence of the contrivance is too evident to require fur ther comment,

Torquay, Oct. 26

John TOPHAM

\section{Note on the Rhynchosaurus Articeps, Owen}

REFErRING lately to Prof. Owen's description of the Rhynchosaurus ("Palæontology," p. 264), first discovered by myself in $183^{8}-39$, in the New Red Sandstone of Grinshill, near Shrewsbury, I remarked that in speaking of the ichuolites supposed to belong to this animal he says there is an "impression corresponding with the hinder part of the foot, which reminds one of a hind toe pointing backwards, and which, like the hind toe of some birds, only touched the ground." In this account nothing is said of any claw being attached to this hind toe, nor have $I$ met with any description of a claw in other authors. I have therefore thought it worth while to mention that I possess a specimen from Grinshill that shows distinctly the impression of a straight claw pointing backwards. There is also, on the same slab, the impression of another smaller foot of only three toes with strong straight claws, which has behind it a slight impression corresponding with the hind toe of the larger footprints. It is a curious fact that the claws of the larger impression, though larger than those of the smaller fjotprint, are so much recurved as not to project much beyond the ends of the toes, while on another slab from Storeton there are reliefs with both straight and recurved claws, the latter giving the idea of a foot like that of the Great Anteater. In these Storeton ichnolites the hind toe exhibits no claw, nor am I sure whether certain rounded ele. vations represent the smaller footprint in the Grinshill specimen. Upon another slab of Storeton stone I have a mark resembling the tail-mark on the slab presented by Mr. Strickland to the Warwickshire Museum, but unfortunately the footmarks connected with it are too indistinct to decide its origin. In a third slab from Storeton, besides several impressions with straight. claws, there is one three inches long, the second toe of which has a straight claw $\frac{5}{5}$ in. in length. I have also Cheirotherium footprints with long straight claws from the same quarries.

I have put these few remarks together to fulfl the wish of Prof. Owen " to obtain the means of determining the precise modifications of the locomotive extremities of the Rhynchosaurus." Perhaps by this time this object may have been attained, for at the Congrès des Savans at Paris in 1868 the discovery of two almost perfect skeletons was announced, and drawings of them were exhibited by a professor from Lyons.

T. OGIER WARD

[So far as the photographs can be deciphered, they seem to bear out the writer's statements. - E.D.]

\section{THE ALPINE CLUB MAP OF SWITZER- $\angle A N D^{*}$}

T NATURE, yol. vi. p. 203 , we adverted to the nonexistence of a map of the Alps on a scale sufficiently large for general purposes, and briefly, referred to the map which was then being produced under the direction of a committee of the English Alpine Club with the view of supplying the want. This map, though not yet finished, has been recently published. Three sheets are completely finished, but the fourth is still in outline, and will be exchanged for perfect copies when the hill-shading is added.

We believe this to be, so far as it extends, the most exact map of the Alps which has yet appeared, and probably no map of its size has ever been produced in this country with more beautiful workmanship or with greater

* The Alpine Club Map of Switzetland with parts of the neighbouring countries, Edited by R. C. Nichols, F.S.A., F.R.G,S., under the superintendence of a Committee of the Alpine Club. In four sheets. Scale $25 \sigma^{i} \delta 00$ (Stanford, 1874 ) 
elaboration of detail. We could have wished, indeed, that details had been inserted somewhat less profusely. It can nevcr be possible in maps of the scale of this one (about one-quarter of an inch to a mile) to render, with a sufficient degree of clearness, all the minutia which are inserted in the great Government Surveys of civilised countries; nor can it ever have been supposed that this map would do away with the necessity of smaller maps of separate districts on a larger scale. Yet we find, in the map under review, in innumerable places, a mass of details which would have been amply sufficient had it been four times its dimensions, and a consequent want of clearness which is not a little perplexing. In some places, even the fantastic passes made in late years by the followers of the high art of mountaineering hate been inserted, whilist in others (in the chain of Mont Blanc, for example) they have been almost entirely omitted, simply from want of space. Thus it appears, to those who are not informed, that in some places there are a great number of such passes, and in others scarcely any, when the reverse is perhaps the case. We should have advocated, both for the sake of consistency and of clearness, the omission of all passes except those of distinct utility.

In point of cleamess it must be admitted that the English Alpine Club Map is scarcely equal to the reduction of the Carte Dufour which was published last year in Switzerland, * and this is not surprising. The authorities at Bern had to produce a simple reduction of the twenty-five sheet map of Switzerland, which was intended to be useful for general purposes, and to be issued at a low price so that it might be within the reach of everyone, and in this they have succeeded admirably. They had at their command most of the members of the staff who had becn employed upon the survey, and thus had little or no difficulty in determining what to omit. This was a great advantage; for it must bc obvious to all that, in reducing a map to a much smaller scale, it is more easy to determine what should be inserted than it is to know what should be left out. This simple fact, no doubt, accounts to some extent for the over-elaboration of the Alpine Club Map to which we just now referred. Its projectors also adopted the Carte Dufour as the basis of their map so far as Switzerland was concerned, but they had not the command of the very exact and minute topographical information which was possessed at Bern.

The reduced Swiss map, like the Carte Dufour, is a map of Switzerland, and for the most part stops abruptly at the frontier. The English map, however, is a map of Switzerland with parts of the neighbowno conntrits. I exiends everywhere sixteen miles more to the south than the most southern point of the Swiss boundarics, and in some places the country which it embraces (which is not included in the Swiss map) is as much as sixty-five to seventy miles from north to south. In the north and in the west the limits of the two maps are nearly the same, but in the east the English one includes the Orteler and scveral other important greups of mountains, which are not given in the Swiss one. The superficial area of the Alpine portion of the English map is altogether about one-half greater than that of the other, and the chief value of the map will be found to be in the part of it that represents this land beyond, but bordering the Swiss fronticrs.

It was a comparatively easy task, notwithstanding the complicated and exceedingly elaborate nature of the engraving, to render Switzerland after the Carte Dufour. The chief difficulty in the production of the map has lain in obtaining the material necessary for its completion towards the south. When it was commenced-now nearly ten years ago-there was no map, even respectably accurate, of the chain of Mont Blanc in existence ; and thence, right away to the furthest land in the east which is

* Karte der Schweir, in 4 bhittern, rednciert unter der Direction des Herm General G. H. Dufout. Maassab, 2 thot $^{2}$ (Dern, i $S_{73}$ ) included, scarcely a square league could be adopted with confidence from any published survey. Hence it was necessary not only to cxamine every individual mountain and valley, but absolutely to re-survey several large districts. The chain of Mont Blanc, as it appears in the Alpine Club Map, is mainly taken from the special survey of Mr. Adams Reilly; * and so, too, is the whole of the southern side of Monte Rosa, as well as the large district bounded on the east by the Val d'Ayas, on the south by the valley of Aosta, and on the west by the valley of Valpelline.t This Iast-named district alone includes more than 150 square miles. The Graian Alps were in a state of hopeless confusion when Mr. R. C. Nichols took them in hand, and anyone who compares the map moler notice with the best which were published previously will see what radical changes and corrections have been effected. Altogcther, there is in the Alpine Club Map not less than a thousand square miles which have been entirely remodelled, and, for the most part, re-surveyed : this, moreover, being some of the most rugged and dificult country in Europe, containimes numerous peals from $12,000 \mathrm{ft}$. to $13,000 \mathrm{ft}$. elevation.

Those who have been concerned in the production of the Alpine Club Map of Sivitzerland have a right to be proud of their work. We have tested it in the Alps, and it has stood the scrutiny extremely well. We cordially hope, though scarcely expect, that it will prove remunerative to its publisher, and that he will be induced to complete it by adding sheets to the east and to the west, so that at length there may be at least on map of the grandest and most picturesque chain of mountains in the world. In conclusion, a word is due to the engravers. The work was commenced by the late Dr. Keith Johnston, but the greater and the most difficult portions have been executed by Mr. John Addison. We have rarely seen better hill-engtaving ; and the wonder is, not that the appearance of the map has been delayed so long, but that a work of such maguitude and extraordinary minuteness should have been completed so soon.

E. WV

\section{REPORT OF PROF. PARKER'S HUNTERIAN LECTURES "ON THE STRUCTURE AND DEVELOPMENT OF THE VERTEBRATE} SKULL" "

VIII.--Shuli of the Common Fowl (Gallus domesticus).

$T$ HF skull of birds is romarkabic for the great amount of anchylosis which takes place between its various constituents long before the period of adult life. So complete is this union, that the determination of the separate bones in a full-grown bird is a perfectly hopeless task, without first studying their relation at a period when they retain their criginal distinctness. It will therefore be convenient to describe the fowl's skull, in the first instance, at the pcriod of hatching, when the chicf ossific centres are still separate, although most of the distinctive characters of the adult are already assumed.

In this stage the foramen magnum is surrounded by the four perfectly distinct elements of the occipital segment, between which extensive tracts of cartilage still exist. The basi-occipital is comparatively small, and forms almost exclusively the rounded condyle (Fig. 27 $0 . \mathrm{C})$; the cx-occipital and supra-occipital are large and expanded, and into the latter extends the anterior semicircular canal (Fig. 26, a.s.c.), so largely developed in birds. The prootic (Fig. 26, Pr.O) is well seen on the inner sicle of the cranial cavity, but outside is completely hidden by the great development of the squamosal, which takes a very considerable share in the formation of the side wall of the skull. Two other auditory bones have 